\title{
Improvement of the quality in hydroponically grown fresh aromatic herbs by inducing mild salinity stress is species-specific
}

\author{
Danai-Christina Aktsoglou ${ }^{1, * \odot}$, Dimitrios S. Kasampalis ${ }^{1 \oplus}$, Eirini Sarrou ${ }^{2 \odot}$, \\ Pavlos Tsouvaltzis $^{1 \oplus}$, Paschalina Chatzopoulou ${ }^{2 \oplus}$, Stefan Martens ${ }^{3 \oplus}$, \\ Anastasios S. Siomos ${ }^{1 \oplus}$
}

\author{
${ }^{1}$ Department of Horticulture, Aristotle University of Thessaloniki, 54124 Thessaloniki, Greece \\ ${ }^{2}$ Department of Medicinal and Aromatic Plants, Hellenic Agricultural Organization DEMETER, Institute of Plant Breeding and \\ Genetic Resources, Thermi, 57001 Thessaloniki, Greece \\ ${ }^{3}$ Research and Innovation Centre, Fondazione Edmund Mach, Via E. Mach 1, San Michele all'Adige, (TN), Italy
}

\begin{abstract}
Profitable hydroponic production requires high quality fresh water, which is often not available for agricultural use, while desalinisation of salty water is an expensive and unsustainable technology. In the present study, we assessed the effect of mild salinity stress during the soilless cultivation of fresh peppermint and spearmint in the floating system on biomass yield, produce quality and plant secondary metabolite content. Peppermint and spearmint plants were grown for 25 days on a nutrient solution (NS) supplemented with three different $\mathrm{NaCl}$ concentrations $(0 \mathrm{mM}, 10 \mathrm{mM}$ or $20 \mathrm{mM}$ $\mathrm{NaCl}$ ). The plant height, root length, fresh and dry weight were recorded and composition was determined on fresh tissue. The composition of essential oil was determined upon hydrodistillation and that of polyphenolic compounds by targeted ultra-performance liquid chromatography coupled with mass spectrometer (UPLC-MS/MS). Plant growth was not suspended by the addition of $\mathrm{NaCl}$ in the $\mathrm{NS}$, except for the plant height at the highest salinity level. In peppermint, the nutritional composition was not affected by the salinity, whereas it was significantly improved in spearmint as confirmed by the nitrate content decrease and the total antioxidant capacity, total soluble phenol, total carotenoid and essential oil content increases. Simultaneously, no effect of the salinity on essential oil or polyphenolic composition in both plants was induced. In conclusion, peppermint and spearmint production is feasible in the floating system even under mild salinity conditions, without negatively affecting either the crop yield or the plant's essential oil or phenolic composition. Indeed, low salinity levels improved the nutritional composition of spearmint plants.
\end{abstract}

Keywords: abiotic stress, antioxidants, essential oil, polyphenols, sodium chloride, soilless production

Abbreviations: $\mathrm{AEAC}$, ascorbic acid equivalents; $\mathrm{CaCl}_{2}$, calcium chloride; $\mathrm{CO}_{2}$, carbon dioxide; EC, electrical conductivity; GAE, gallic acid equivalents; GC-MS, Gas Chromatography-Mass Spectroscopy; LSD, least significant differences; $\mathrm{NaCl}$, sodium chloride; NS, nutrient solution; UPLC-MS/MS, ultra-performance liquid chromatographytandem mass spectrometry.

\section{INTRODUCTION}

Soil salinisation is one of the detrimental effects of climate change, and it is often combined with low quality water during irrigation and poor soil drainage, especially in semi-arid regions all over the world

\footnotetext{
*Corresponding author.

e-mail: daktsogl@agro.auth.gr (Danai-Christina Aktsoglou).
} 
(Arslan et al., 2018; Rezaie et al., 2019). Moreover, fresh groundwater is slowly converted into saline water and thus rendered unsuitable for agricultural use, due to excessive pumping for irrigation use followed by seawater fusion, waterlogging and nutrient leaching (Alaghmand et al., 2013; Pulido-Bosch et al., 2018). These factors have triggered growers' willingness to shift towards hydroponic vegetable production (Niu et al., 2018), which however requires the use of optimum quality water that is unfortunately not always available for agricultural activities (Niu et al., 2018; Yousefi et al., 2020). Deterioration of groundwater quality often imposes the need for establishment of desalinisation water treatment technologies, such as the reverse osmosis technique, which not only are substantially expensive but also simultaneously convert only part of the source water into water suitable for irrigation and reject the remaining, which typically amounts to around $60 \%$, due to extreme salinity loading (Arslan et al., 2018; Niu et al., 2018; Pulido-Bosch et al., 2018; Atzori et al., 2019).

Using low quality water with high electrical conductivity (EC) carrying a large amount of salts such as sodium chloride $(\mathrm{NaCl})$ causes the absorption and over-accumulation of sodium and chloride ions in tissues, which subsequently induce severe salt toxicity, tissue dehydration, nutrient imbalance and oxidative stress (Munns, 1993; Lazof et al., 1998). On the other hand, it has been demonstrated that modification of the EC in the nutrient solution (NS) has efficiently improved the quality of some vegetables, and such a practice has already been recommended for use in agricultural production (Rouphael et al., 2012). Furthermore, salinity stress may even induce secondary metabolism in plants and, consequently, the accumulation of human health promoting secondary metabolites, such as terpenes and polyphenolic compounds (Tarchoune et al., 2013; Tounekti et al., 2011; Verma and Shukla, 2015; Thakur et al., 2019).

The floating tray system exhibits many advantages in comparison to other hydroponic systems, such as low installation cost, simplicity and functionality of operation, high water and nutrient use efficiency, accelerated cultivation cycles and eventually total absence of soil residues from the harvested produce (Rodríguez-Hidalgo et al., 2010). Several aromatic plants of the Lamiaceae family are suitable to be grown in this hydroponic system, given that there is a significant demand for a high volume of water in order to increase crop yield (Peter, 2001). Peppermint (Mentha $\times$ piperita L.) and spearmint (Mentha spicata L.) are two perennial herbs of high economic value, from which a combination of uses can be obtained, including in cooking, phytomedicine and food industry (Charles, 2013). They are consumed fresh or dry and are rich in phytonutrients, such as vitamins, minerals and natural antioxidants (Peter, 2001; Charles, 2013).
Spearmint cultivation using the deep flow technique has already been successfully tested (Vimolmangkang et al., 2010; Chrysargyris et al., 2017); however, there is no available literature relevant to peppermint production. Moreover, the response of these two species to salinity has only been studied under extreme treatments with high salt concentration.

Therefore, the aim of this study was to investigate the feasibility of a commercial soilless production of peppermint and spearmint on the floating trays system, as well as to assess the possibility of adapting mild salinity conditions in the NS of a non-recirculating closed hydroponic system as a tool to improve the quality and nutritional value of fresh peppermint and spearmint plants.

\section{MATERIALS AND METHODS}

\section{Hydroponic system}

A floating hydroponic system was established in a glasshouse at the Aristotle University of Thessaloniki farm (Thermi, Greece) during April-May 2019. Nine plastic basins $(70 \mathrm{~cm} \times 65 \mathrm{~cm} \times 20 \mathrm{~cm}, \mathrm{~L} \times \mathrm{W} \times \mathrm{H})$ were filled with $50 \mathrm{~L}$ of NS each (Table 1) and were adjusted to three salinity levels with the addition of $0 \mathrm{mM}, 10 \mathrm{mM}$ or $20 \mathrm{mM} \mathrm{NaCl}$. Three replicates were used per salinity level with one basin per replicate. During the cultivation, the mean temperature inside the greenhouse ranged between $19.4{ }^{\circ} \mathrm{C}$ and $29.9^{\circ} \mathrm{C}$ and the mean relative humidity between $49.3 \%$ and $71.4 \%$.

\section{Plant material and treatments}

Peppermint and spearmint rooted grafts were collected from two local populations preserved in the Department of Medicinal and Aromatic Plants of the Institute of Plant Breeding and Genetic Resources (Thermi, Greece). The grafts were transplanted at a density of 230 plants per square metre on expanded polystyrene trays filled with a commercial enriched peat substrate. The peat substrate was Klasmann Potgrond $\mathrm{H}$ with the following composition and properties: $70 \%$ frozen through black peat and 30\% white peat, fine structure $(0-8 \mathrm{~mm})$, fertiliser level $=1.5 \mathrm{~g} \cdot \mathrm{L}^{-1}, 210 \mathrm{mg} \cdot \mathrm{L}^{-1} \mathrm{~N}$,

Table 1. The composition of the NS used in the floating tray system for peppermint and spearmint cultivation.

\begin{tabular}{lrlr}
\hline \multicolumn{2}{l}{ Macronutrients $\left(\mathrm{mg} \cdot \mathrm{L}^{-1}\right)$} & \multicolumn{2}{l}{ Micronutrients $\left(\mu \mathrm{g} \cdot \mathrm{L}^{-1}\right)$} \\
\hline $\mathrm{N}^{-N_{3}}{ }^{-}$ & 210 & $\mathrm{Fe}$ & 1150 \\
$\mathrm{~N}-\mathrm{NH}_{4}^{+}$ & 14 & $\mathrm{Mn}$ & 399 \\
$\mathrm{~K}$ & 391 & $\mathrm{Zn}$ & 150 \\
$\mathrm{P}$ & 62 & $\mathrm{Cu}$ & 150 \\
$\mathrm{Mg}$ & 49 & $\mathrm{~B}$ & 500 \\
$\mathrm{Ca}$ & 385 & $\mathrm{Mo}$ & 48 \\
$\mathrm{~S}$ & 232 & & \\
\hline
\end{tabular}

NS, nutrient solution. 
$240 \mathrm{mg} \cdot \mathrm{L}^{-1} \mathrm{P}_{2} \mathrm{O}_{5}, 270 \mathrm{mg} \cdot \mathrm{L}^{-1} \mathrm{~K}_{2} \mathrm{O}, 100 \mathrm{mg} \cdot \mathrm{L}^{-3} \mathrm{Mg}$, $<10 \%$ dry matter, $80-85 \%$ water capacity, 5-10\% air capacity, $\mathrm{pH}\left(\mathrm{H}_{2} \mathrm{O}, \mathrm{v} / \mathrm{v} 1: 1.25\right)=6.0, \mathrm{EC}=0.45 \mathrm{dS} \cdot \mathrm{m}^{-1}$, dry density $=160 \mathrm{~kg} \cdot \mathrm{m}^{-3}$. The trays were placed in the greenhouse and watered daily for 3 weeks until successful rooting. Then the plants were trimmed to obtain a uniform height and two trays containing 36 peppermint and 36 spearmint plants were placed in each basin.

The NSs were stirred frequently to ensure adequate aeration of the roots. After stirring, the $\mathrm{pH}$ and $\mathrm{EC}$ were recorded using a portable instrument (C5020, Consort, Turnhout, Belgium).

Twenty plants in each treatment were harvested after 24 days while still being at the vegetative herbaceous stage. Plant height and root length were recorded in planta before harvest, while plant weight was measured immediately after harvest. A total of $50 \mathrm{~g}$ and $10 \mathrm{~g}$ of fresh tissue from each treatment were used for the essential oil extraction and polyphenolic analysis, respectively. The remaining tissue was kept at $-20{ }^{\circ} \mathrm{C}$ for compositional analysis.

Frozen tissue of peppermint and spearmint was homogenised in a waring blender, a mortar and pestle; and the homogenised tissue was used to determine the composition and total antioxidant capacity.

Dry matter was determined after drying $30 \mathrm{~g}$ of homogenised tissue at $70{ }^{\circ} \mathrm{C}$ for $72 \mathrm{~h}$. The total soluble solids were determined with the use of a portable digital refractometer (PAC-1, Atago Co Ltd., Tokyo, Japan) in juice obtained after squeezing the homogenised tissue.

Nitrate content was determined following the method of Cataldo et al. (1975).

The total antioxidant capacity was determined following the method of Brand-Williams et al. (1995) using an ascorbic acid standard curve and expressed as milligram ascorbic acid equivalents (AEAC) $\cdot 100 \mathrm{~g}^{-1}$ in fresh weight (f.w.), while the total soluble phenol content was determined following the method of Scalbert et al. (1989), using a gallic acid curve and expressed as milligram gallic acid equivalents (GAE) $\cdot \mathrm{kg}^{-1}$ in f.w., on a Thermo Spectronic Helios Alpha UV-Vis spectrophotometer (Thermo Fisher Scientific, Waltham, MA, USA).

For the extraction of pigments, $10 \mathrm{~mL}$ acetone was added to $0.2 \mathrm{~g}$ of homogenised tissue and incubated at $-20{ }^{\circ} \mathrm{C}$ overnight. The following day, total chlorophyll and total carotenoids content were determined according to the method of Lichtenthaler and Wellburn (1983).

\section{Essential oil}

The essential oil content was determined on hydrodistillation of $50 \mathrm{~g}$ samples of fresh tissue previously cut into small pieces, using a European Pharmacopoiea apparatus (Clevenger-type) for $2.5 \mathrm{~h}$, with a distillation rate of $3-3.5 \mathrm{~mL} \cdot \mathrm{min}^{-1}$. The essential oil was dried over anhydrous sodium sulphate and was stored at $4-6{ }^{\circ} \mathrm{C}$ until analysis.
The essential oil was analysed by gas chromatography-mass spectroscopy (GC-MS) on a Shimadzu GC 17A Ver. 3 coupled with Mass Spectrometer QP-5050A (Shimadzu Europa GmbH, Germany), supported by Class 5000 software. The analysis was performed on a fused silica DB-5 capillary column, with the following conditions: injection point temperature $260^{\circ} \mathrm{C}$, ion source temperature $200^{\circ} \mathrm{C}$, GCMS connection temperature $300^{\circ} \mathrm{C}$, Electron Ionisation $70 \mathrm{eV}$, scanning range 41-450 amu and scanning time $0.50 \mathrm{~s}$. The oven temperature programmes applied were (a) $55-120^{\circ} \mathrm{C}\left(3{ }^{\circ} \mathrm{C} \cdot \mathrm{min}^{-1}\right), 120-200{ }^{\circ} \mathrm{C}\left(4^{\circ} \mathrm{C} \cdot \mathrm{min}^{-1}\right)$, 200-220 ${ }^{\circ} \mathrm{C}\left(6^{\circ} \mathrm{C} \cdot \mathrm{min}^{-1}\right)$ and $220{ }^{\circ} \mathrm{C}$ for $5 \mathrm{~min}$, and (b) $60-240{ }^{\circ} \mathrm{C}\left(3{ }^{\circ} \mathrm{C} \cdot \mathrm{min}^{-1}\right)$. The carrier gas was $\mathrm{He}$, $54.8 \mathrm{kPa}$ and the sample inlet ratio was $1: 30$.

The relative to $n$-alkanes $(\mathrm{C} 8-\mathrm{C} 20)$ retention indices (RI) of the compounds were used for their identification, for comparing them with the respective reference substances (Adams, 2007) and for comparing the spectra with similar mass spectra of the MS libraries NIST 98 and Wiley 1995. The relative content of each compound was calculated as a percentage of the total chromatographic area.

\section{Polyphenolic compounds}

Samples of $10 \mathrm{~g}$ of the fresh plant tissue of each treatment was freeze-dried (Freeze-dryer Alpha 1-2 LD plus, Christ, Osterode, Germany) at $-24{ }^{\circ} \mathrm{C}$, and pulverised to fine powder; subsequently, $200 \mathrm{mg}$ of freeze-dried tissue powder was extracted with $10 \mathrm{~mL} \mathrm{80 \%} \mathrm{methanol}$ into $15 \mathrm{~mL}$ falcon tubes. The samples were mixed on an orbital shaker for $3 \mathrm{~h}$ at room temperature and stored overnight at $4{ }^{\circ} \mathrm{C}$ in the dark. The extracts were filtered on a MILLEX $0.22 \mathrm{~mm}$ PFTE membrane (Merck Millipore, Darmstadt, Germany) into a glass vial and were analysed for polyphenolics composition in an ultraperformance liquid chromatography coupled with mass spectrometer (UPLC-MS/MS), as described below.

Targeted UPLC-MS/MS analysis was performed on a Waters Acquity system (Milford, MA, USA), consisting of a binary pump, an online vacuum degasser, an autosampler and a column compartment. Separation of the phenolic compounds was achieved on a Waters Acquity HSS T3 column $(1.8 \mathrm{~mm}, 100 \mathrm{~mm} \times 2.1 \mathrm{~mm})$, kept at $40{ }^{\circ} \mathrm{C}$. The analysis of the phenolic compounds was performed using the method described previously by Vrhovsek et al. (2012). Mass spectrometry detection was performed on a Waters Xevo TQMS instrument equipped with an electrospray (ESI) source. Data processing was performed using the Mass Lynx Target Lynx Application Manager (Waters).

\section{Experimental design and statistical analysis}

Analysis of variance of the data was performed in SPSS v.24 (IBM, USA) using a completely randomised design with three replicates per $\mathrm{NaCl}$ concentration. Means were compared with the least significant differences (LSD) test at $p<0.05$. 


\section{RESULTS}

\section{EC and $p H$ of $N S$}

Figure 1 illustrates the EC (A) and $\mathrm{pH}(\mathrm{B})$ in the NSs during the cultivation of plants. The EC of the two salinity treatments $(10 \mathrm{mM}$ and $20 \mathrm{mM} \mathrm{NaCl})$ was
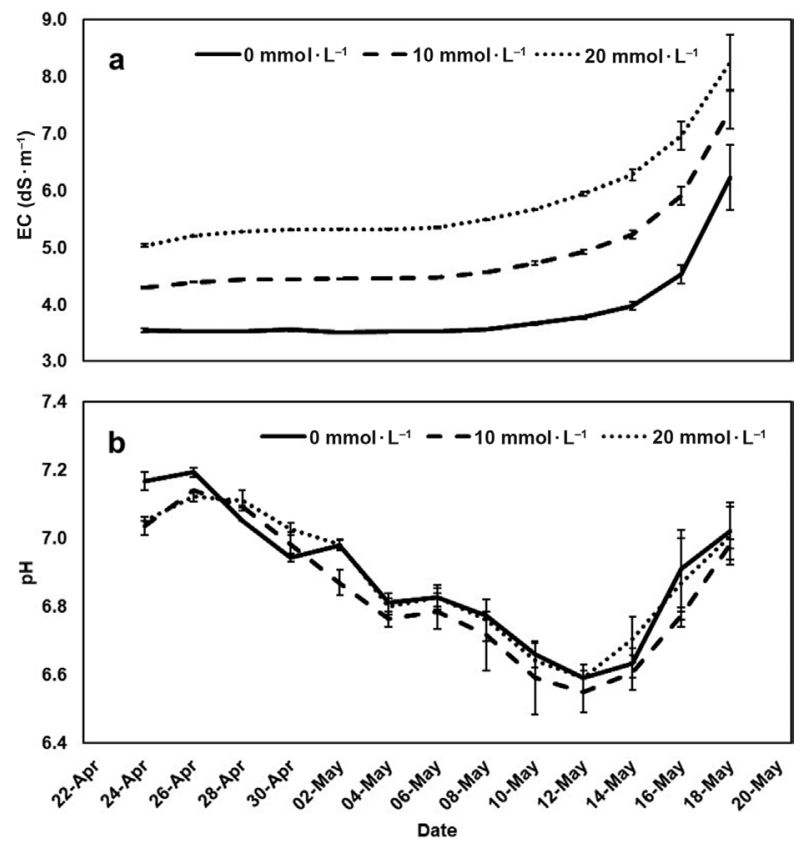

Figure 1. EC (A) and $\mathrm{pH}(\mathrm{B})$ of the NSs supplemented with $0 \mathrm{mmol} \cdot \mathrm{L}^{-1}, 10 \mathrm{mmol} \cdot \mathrm{L}^{-1}$ or $20 \mathrm{mmol} \cdot \mathrm{L}^{-1}$ $\mathrm{NaCl}$ during peppermint and spearmint cultivation in floating system. Each value is a mean of three replicates and each replicate consists of one basin. EC, electrical conductivity; NSs, nutrient solutions. significantly higher $\left(4.2 \mathrm{mS} \cdot \mathrm{cm}^{-1}\right.$ and $5.0 \mathrm{mS} \cdot \mathrm{cm}^{-1}$, respectively) than that of the control $\left(3.5 \mathrm{mS} \cdot \mathrm{cm}^{-1}\right)$, which followed the same pattern, remaining constant for most part of the cultivation period, beginning to rise only after 18 days, and reaching the maximum levels on the day of harvest $\left(5.8 \mathrm{mS} \cdot \mathrm{cm}^{-1}, 7.0 \mathrm{mS} \cdot \mathrm{cm}^{-1}\right.$ and $7.5 \mathrm{mS} \cdot \mathrm{cm}^{-1}$, respectively, for $0 \mathrm{mM}, 10 \mathrm{mM}$ and $20 \mathrm{mM} \mathrm{NaCl}$ ) (Figure 1A). The $\mathrm{pH}$ of the NS in all treatments was 7.1-7.2 at the beginning of the cultivation period and following the same trend it was constantly declining, reaching the lowest value of 6.6 in all solutions 1 week before harvest, when it began to rise again rapidly, climbing up to the initial values (Figure 1B).

\section{Plant growth and yield}

The addition of $\mathrm{NaCl}$ in the NS did not affect the $\mathrm{f}$. w. or the dry matter in both peppermint and spearmint, but the plant height was significantly decreased by $18.5 \%$ and $11.8 \%$, respectively, only when the plants were grown on the highest salinity levels (Table 2). Furthermore, root length was significantly reduced only in spearmint plants at the highest salinity, as well (Table 2).

\section{Composition}

Sodium chloride supplement in the NSs of peppermint plants did not affect their composition (Table 2). In spearmint plants, however, the addition of $20 \mathrm{mmol} \cdot \mathrm{L}^{-1}$ $\mathrm{NaCl}$ in the NS induced significant changes in several components. In particular, the nitrate content had decreased, while the total antioxidant capacity, the total soluble phenols and the total carotenoids had increased. Moreover, the essential oil content of spearmint

Table 2. Plant growth and the compositional characteristics of peppermint and spearmint plants grown in floating system under three $\mathrm{NaCl}$ concentrations $\left(0 \mathrm{mmol} \cdot \mathrm{L}^{-1}, 10 \mathrm{mmol} \cdot \mathrm{L}^{-1}\right.$ or $\left.20 \mathrm{mmol} \cdot \mathrm{L}^{-1}\right)$.

\begin{tabular}{|c|c|c|c|c|c|c|c|c|}
\hline & \multicolumn{4}{|c|}{ Peppermint } & \multicolumn{4}{|c|}{ Spearmint } \\
\hline & \multicolumn{3}{|c|}{$\mathrm{NaCl}$ concentration } & \multirow[b]{2}{*}{$p$} & \multicolumn{3}{|c|}{$\mathrm{NaCl}$ concentration } & \\
\hline & $0 \mathrm{mmol} \cdot \mathrm{L}^{-1}$ & $10 \mathrm{mmol} \cdot \mathrm{L}^{-1}$ & $20 \mathrm{mmol} \cdot \mathrm{L}^{-1}$ & & $0 \mathrm{mmol} \cdot \mathrm{L}^{-1}$ & $10 \mathrm{mmol} \cdot \mathrm{L}^{-1}$ & $20 \mathrm{mmol} \cdot \mathrm{L}^{-1}$ & $p$ \\
\hline Fresh weight $(\mathrm{g})$ & $10.2^{x}$ & 9.35 & 8.05 & $\mathrm{~ns}^{\mathrm{y}}$ & 8.05 & 7.42 & 6.82 & ns \\
\hline Plant height $(\mathrm{cm})$ & $22.83 \mathrm{a}^{\mathrm{z}}$ & $21.13 \mathrm{a}$ & $18.61 \mathrm{~b}$ & $* *$ & $24.06 \mathrm{a}$ & $23.32 \mathrm{a}$ & $21.23 \mathrm{~b}$ & $*$ \\
\hline Root length (cm) & 12.97 & 14.41 & 12.81 & ns & $11.48 \mathrm{a}$ & $11.26 \mathrm{a}$ & $9.55 \mathrm{~b}$ & $*$ \\
\hline Dry matter $(\%)$ & 14.2 & 13.9 & 15.1 & ns & 17.2 & 17.8 & 19.8 & ns \\
\hline Total soluble solids (\%) & 9.5 & 8.8 & 9.7 & ns & 9.5 & 9.7 & 10.2 & ns \\
\hline Nitrates (mg $\cdot \mathrm{kg}^{-1}$ f.w.) & 828.5 & 855.7 & 766.6 & ns & $797.3 \mathrm{a}$ & $721.4 \mathrm{a}$ & $548.9 \mathrm{~b}$ & $*$ \\
\hline $\begin{array}{l}\text { Total antixidant capacity } \\
\left(\mathrm{mg} \mathrm{AEAC} \cdot 100 \mathrm{~g}^{-1} \text { f.w.) }\right.\end{array}$ & 110.3 & 93.8 & 160.7 & ns & $65.0 \mathrm{~b}$ & $78.6 \mathrm{~b}$ & 115.7 a & $* *$ \\
\hline $\begin{array}{l}\text { Total soluble phenols } \\
\text { (mg GAE } \cdot \mathrm{kg}^{-1} \text { f.w.) }\end{array}$ & 0.467 & 0.417 & 0.663 & $\mathrm{~ns}$ & $0.367 \mathrm{~b}$ & $0.447 \mathrm{~b}$ & $0.577 \mathrm{a}$ & $* *$ \\
\hline $\begin{array}{l}\text { Total chlorophyll } \\
\left(\mu \mathrm{g} \cdot \mathrm{g}^{-1} \text { f.w.) }\right.\end{array}$ & 1138.4 & 1130.0 & 1133.9 & $\mathrm{~ns}$ & 1173.4 & 1241.6 & 1287.7 & ns \\
\hline $\begin{array}{l}\text { Total carotenoids } \\
\left(\mu \mathrm{g} \cdot \mathrm{g}^{-1} \text { f.w. }\right)\end{array}$ & 200.4 & 196.5 & 201.9 & $\mathrm{~ns}$ & $204.7 \mathrm{~b}$ & $218.4 \mathrm{~b}$ & $234.8 \mathrm{a}$ & $* *$ \\
\hline $\begin{array}{l}\text { Essential oil } \\
\left(\mathrm{ml} \cdot 100 \mathrm{~g}^{-1} \text { f.w. }\right)\end{array}$ & 0.34 & 0.35 & 0.37 & $\mathrm{~ns}$ & $0.19 \mathrm{~b}$ & $0.21 \mathrm{a}$ & $0.22 \mathrm{a}$ & $*$ \\
\hline
\end{tabular}

${ }^{x}$ Values are means of three replicates.

y*, **,*** shows significant differences at $0.05,0.01$ and 0.001 probability levels; ns shows non-significant differences.

${ }^{z}$ Values in the same row followed by different letters differ significantly by LSD test $(p<0.05)$. 
increased in both salinity levels by $10.5 \%$ and $15.8 \%$, respectively. Neither the total soluble solids nor the total chlorophyll content were affected by the salinity treatments (Table 2).

\section{Essential oil and polyphenolic composition}

The addition of $\mathrm{NaCl}$ in the NS did not affect either the essential oil (Table 3) or the polyphenolic composition (Table 4) of both peppermint and spearmint fresh tissue. The only significant difference observed in the compounds of the essential oil of spearmint was of 3-octanol, which was increased under $\mathrm{NaCl}$ treatment, but its individual concentration is quite low in relation to the overall composition of the essential oil.

\section{DISCUSSION}

In the floating system, as water and nutrient uptake is a continuous function during plant growth and development, an NS depletion as well as a nutrient imbalance may be exhibited due to the absorption of specific ions at a higher rate than others, thus causing a modification of both $\mathrm{EC}$ and $\mathrm{pH}$ of the solution. A rapid increase in EC may be observed when low quality saline water is used, especially in arid and semi-arid areas, as non-essential ions as $\mathrm{Na}^{+}$and $\mathrm{Cl}^{-}$accumulate in the NS (Urrestarazu and García, 2000). Changes in the $\mathrm{pH}$ of the NS are also induced, as roots release $\mathrm{H}^{+}$and $\mathrm{HCO}_{3}^{-}$ions during nutrient uptake (Hinsinger et al., 2003). In the present study, the rapid increase of EC and the changes in the $\mathrm{pH}$ of the solutions cannot be attributed solely to the presence of $\mathrm{NaCl}$, as the control solution followed a similar trend, and therefore may also be attributed to the NS depletion due to evapotranspiration and the change of ionic ratios (Urrestarazu and García, 2000).

Extreme levels of salinity impose a harmful effect on plant growth; the most common morphological, physiological and biochemical parameters that indicate salinity stress are stunted growth, water stress, disruption of metabolic processes and ion uptake, high respiration, synthesis of osmoregulators, disruption of photosynthesis, ion imbalance and inhibition of enzyme activity (Estaji et al., 2018). Although a decrease in plant height was observed in both peppermint and spearmint plants and in root length of spearmint, the fresh and dry biomass and the total soluble solids content were not affected by the presence of $\mathrm{NaCl}$ in the NS, possibly because of the low levels of salinity and the short period of cultivation. The hydroponic production of herbs in NS of medium to high salinity $(20-130 \mathrm{mM} \mathrm{NaCl})$ has shown various responses in plant growth, depending on the species or cultivar, the level of salinity, the type of salt and the period of abiotic stress. Indeed, a negative effect on plant growth was observed in herbs, such as basil, marjoram, mint timija, sage, lavender and mint, grown either hydroponically under salinity or in pots and irrigated with NS with increased $\mathrm{EC}$ due to $\mathrm{NaCl}$ presence (Bernstein et al., 2010; Jelali et al., 2011; Taârit et al., 2011; Tarchoune et al., 2013; Kasrati et al., 2014; Yu et al., 2015; García-Caparrós et al., 2017). The decrease in biomass and yield in plants treated with high amounts of $\mathrm{NaCl}$ may be attributed to stomatal limitations, which in turn restrict carbon dioxide $\left(\mathrm{CO}_{2}\right)$ diffusion into the leaf and induce further osmotic and salt-specific effects, as reported by Noecleous et al. (2017) in melon (Cucumis melo L.) plants grown hydroponically in recirculating NS.

Although the chlorophyll content may be used as an indicator of salt stress, it is affected differently depending on the plant sensitivity and may either decrease or remain unaffected in sensitive species and even increase in tolerant ones (Jungklang, 2003; Lee et al., 2004; Qiu and Lu, 2003). Similar to our results, the chlorophyll content in basil plants was not affected by salinity up to $130 \mathrm{mmol} \cdot \mathrm{L}^{-1} \mathrm{NaCl}$, implying that it is not a reliable indicator of salinity stress for these species.

One quality trait of high importance in green leafy herbaceous plants is their nitrate content. The accumulation of nitrates has triggered the attention of the medical society, because it has been associated with severe human health risks and many countries have adopted regulations setting the maximum accepted nitrate levels in many species produced for human consumption (Santamaria, 2006). The decrease in nitrate content that was observed in spearmint plants may be attributed to the competition between nitrate and chloride ions for the same transporter in the root system (Blom-Zandstra and Lampe, 1983). A similar decrease in nitrate content has been observed in celery grown hydroponically under high saline conditions (50$300 \mathrm{mmol} \cdot \mathrm{L}^{-1} \mathrm{NaCl}$ ) (Pardossi et al., 1999), as well as in lettuce grown in a floating hydroponic system after addition of $5,000-10,000 \mathrm{mmol} \cdot \mathrm{L}^{-1} \mathrm{CaCl}_{2}$ in the NS (Borghesi et al., 2013).

Salinity stress may also have a positive or negative impact in the production of secondary metabolites in plants (Verma and Shukla, 2015; Thakur et al, 2019) and may improve their antioxidant capacity by increasing the synthesis of compounds that act as scavengers, protecting the cells against reactive oxygen species (Dat et al., 2000). Several secondary metabolites, such as carotenoids, polyphenols and essential oil components, are important antioxidants in herbs (Wojdyło et al., 2007; Riachi and De Maria, 2015). Irrespective of the $\mathrm{NaCl}$ concentration in the $\mathrm{NSs}$, the main constituents in the essential oil of peppermint were menthone (55\%), menthol (15\%), menthofuran $(6.5 \%)$ and isomenthone $(6 \%)$ (Table 3$)$ and in the spearmint were carvone $(40 \%)$, limonene (17.5\%), 1-8 cineole (16.5\%) and myrcene (4.5\%). Higher contents of carvone (50-57\%) and lower of limonene $(7-10 \%)$ were found in the aerial parts of spearmint plants that were collected from naturally growing populations (Chauhan et al., 2010; Zekri 
Table 3. Essential oil composition of peppermint and spearmint plants grown in floating system under three $\mathrm{NaCl}$ concentrations $\left(0 \mathrm{mmol} \cdot \mathrm{L}^{-1}, 10 \mathrm{mmol} \cdot \mathrm{L}^{-1}\right.$ or $\left.20 \mathrm{mmol} \cdot \mathrm{L}^{-1}\right)$.

\begin{tabular}{|c|c|c|c|c|c|c|c|c|c|c|}
\hline \multirow[b]{3}{*}{ No. } & \multirow[b]{3}{*}{ compounds } & \multicolumn{5}{|c|}{ Peppermint } & \multicolumn{4}{|c|}{ Spearmint } \\
\hline & & \multicolumn{4}{|c|}{$\mathrm{NaCl}$ concentration } & \multirow[b]{2}{*}{$p$} & \multicolumn{3}{|c|}{$\mathrm{NaCl}$ concentration } & \multirow[b]{2}{*}{${ }^{1} p$} \\
\hline & & $\mathrm{RI}^{\mathrm{a}}$ & $0 \mathrm{mmol} \cdot \mathrm{L}^{-1}$ & $10 \mathrm{mmol} \cdot \mathrm{L}^{-1}$ & $20 \mathrm{mmol} \cdot \mathrm{L}^{-1}$ & & $0 \mathrm{mmol} \cdot \mathrm{L}^{-1}$ & $10 \mathrm{mmol} \cdot \mathrm{L}^{-1}$ & $20 \mathrm{mmol} \cdot \mathrm{L}^{-1}$ & \\
\hline 1 & $\alpha$-thujene & 929 & $0.03^{b}$ & 0.03 & 0.03 & $\mathrm{~ns}^{\mathbf{c}}$ & 0.02 & 0.02 & 0.02 & ns \\
\hline 2 & $\alpha$-pinene & 935 & 0.60 & 0.61 & 0.61 & ns & 1.23 & 1.23 & 1.26 & ns \\
\hline 3 & camphene & 950 & - & - & - & & 0.02 & 0.01 & 0.02 & ns \\
\hline 4 & sabinene & 974 & 0.42 & 0.43 & 0.43 & ns & 1.66 & 1.71 & 1.71 & ns \\
\hline 5 & $\beta$-pinene & 977 & 0.90 & 0.90 & 0.91 & ns & 2.52 & 2.53 & 2.60 & ns \\
\hline 6 & 1-octen-3-ol & 982 & 0.02 & 0.01 & 0.01 & ns & - & - & - & \\
\hline 7 & myrcene & 992 & 0.25 & 0.25 & 0.24 & ns & 4.65 & 4.46 & 4.47 & ns \\
\hline 8 & 3-octanol & 996 & 0.07 & 0.07 & 0.05 & ns & $0.72 \mathrm{~b}^{\mathrm{d}}$ & 0.79 a & $0.81 \mathrm{a}$ & $*$ \\
\hline 9 & pseudolimonene & 1004 & - & - & - & & 0.11 & 0.10 & 0.11 & ns \\
\hline 10 & $\alpha$-terpinene & 1016 & 0.26 & 0.22 & 0.24 & ns & 0.04 & 0.01 & 0.03 & ns \\
\hline 11 & $o$-cymene & 1025 & 0.03 & 0.05 & 0.03 & ns & - & - & - & \\
\hline 12 & limonene & 1029 & 2.22 & 2.30 & 2.32 & ns & 17.57 & 17.99 & 17.97 & ns \\
\hline 13 & 1,8 -cineol & 1032 & 4.14 & 4.11 & 4.29 & ns & 16.44 & 16.34 & 16.86 & ns \\
\hline 14 & cis- $\beta$-ocimene & 1040 & 0.14 & 0.14 & 0.13 & ns & 0.61 & 0.59 & 0.62 & ns \\
\hline 15 & trans- $\beta$-ocimene & 1051 & - & - & - & & 0.12 & 0.13 & 0.14 & ns \\
\hline 16 & $\gamma$-terpinene & 1060 & 0.46 & 0.39 & 0.44 & ns & 0.07 & 0.05 & 0.06 & ns \\
\hline 17 & cis-sabinene hydrate & 1068 & 0.37 & 0.44 & 0.42 & ns & 0.01 & 0.03 & 0.02 & ns \\
\hline 18 & terpinolene & 1087 & 0.12 & 0.11 & 0.11 & ns & 0.09 & 0.08 & 0.08 & ns \\
\hline \multicolumn{3}{|c|}{ Monoterpene hydrocarbons (\%) } & 10.00 & 10.06 & 10.27 & & 45.88 & 46.07 & 46.77 & \\
\hline 19 & linalool & 1100 & 0.10 & 0.10 & 0.09 & ns & 0.11 & 0.12 & 0.10 & ns \\
\hline 20 & trans-pinocarveol & 1139 & - & - & - & & 0.15 & 0.18 & 0.16 & ns \\
\hline 21 & menthone & 1158 & 55.44 & 55.98 & 54.51 & ns & - & - & - & \\
\hline 22 & menthofuran & 1164 & 6.49 & 5.64 & 6.15 & ns & - & - & - & \\
\hline 23 & isomenthone & 1166 & 6.25 & 6.79 & 6.61 & ns & - & - & - & \\
\hline 24 & neomenthol & 1167 & 0.12 & 0.12 & 0.12 & ns & - & - & - & \\
\hline 25 & $\delta$-terpineol & 1167 & - & - & - & & 0.45 & 0.47 & 0.47 & ns \\
\hline 26 & menthol & 1176 & 15.16 & 15.24 & 15.30 & ns & - & - & - & \\
\hline 27 & terpinen-4-ol & 1177 & 1.27 & 1.15 & 1.21 & ns & 0.13 & 0.11 & 0.14 & ns \\
\hline 28 & neoisomenthol & 1182 & 0.07 & 0.07 & 0.07 & ns & - & - & - & \\
\hline 29 & $\alpha$-terpineol & 1189 & 0.14 & 0.13 & 0.13 & ns & 0.91 & 0.94 & 0.92 & ns \\
\hline 30 & dihydrocarveol & 1193 & - & - & - & & 0.11 & 0.09 & 0.08 & ns \\
\hline 31 & trans-dihydrocarvone & 1194 & - & - & - & & 0.12 & 0.13 & 0.12 & ns \\
\hline 32 & trans-carveol & 1219 & - & - & - & & 1.08 & 0.99 & 0.95 & ns \\
\hline 33 & pulegone & 1238 & 1.76 & 1.68 & 1.73 & ns & - & - & - & \\
\hline 34 & carvone & 1247 & - & - & - & & 40.64 & 40.54 & 39.49 & ns \\
\hline 35 & piperitone & 1253 & 0.49 & 0.50 & 0.50 & ns & - & - & - & \\
\hline 36 & dihydroedulan II & 1284 & - & - & - & & 0.13 & 0.14 & 0.18 & ns \\
\hline 37 & menthyl acetate & 1294 & 0.42 & 0.58 & 0.65 & ns & - & - & - & \\
\hline \multicolumn{3}{|c|}{ Oxygenated monoterpenes (\%) } & 87.71 & 87.97 & 87.08 & & 43.83 & 43.71 & 42.61 & \\
\hline 38 & $\alpha$-copaene & 1376 & - & - & - & & 0.02 & 0.03 & 0.03 & ns \\
\hline 39 & $\beta$-bourbonene & 1383 & - & - & - & & 0.49 & 0.54 & 0.58 & ns \\
\hline 40 & $\beta$-elemene & 1391 & - & - & - & & 0.18 & 0.18 & 0.19 & ns \\
\hline 41 & $\beta$-caryophyllene & 1415 & 0.60 & 0.54 & 0.74 & ns & 3.82 & 2.69 & 3.89 & ns \\
\hline 42 & $\alpha$-humulene & 1451 & - & - & - & & 0.17 & 0.17 & 0.18 & ns \\
\hline 43 & cis- $\beta$-farnesene & 1461 & 0.11 & 0.10 & 0.13 & ns & 0.11 & 0.11 & 0.11 & ns \\
\hline 44 & germacrene-D & 1479 & 1.01 & 0.84 & 1.17 & ns & 4.35 & 4.03 & 4.22 & ns \\
\hline 45 & bicyclogermacrene & 1492 & 0.09 & 0.07 & 0.10 & ns & 0.37 & 0.35 & 0.38 & ns \\
\hline 46 & $\delta$-cadinene & 1525 & - & - & - & & 0.09 & 0.09 & 0.10 & ns \\
\hline \multicolumn{3}{|c|}{ Sesquiterpene hydrocarbons (\%) } & 1.82 & 1.54 & 2.14 & & 9.61 & 8.20 & 9.67 & \\
\hline 47 & caryophyllene oxide & 1584 & - & - & - & & 0.04 & 0.02 & 0.04 & ns \\
\hline 48 & viridiflorol & 1591 & 0.26 & 0.25 & 0.26 & ns & - & - & - & \\
\hline
\end{tabular}


Table 3. Continued

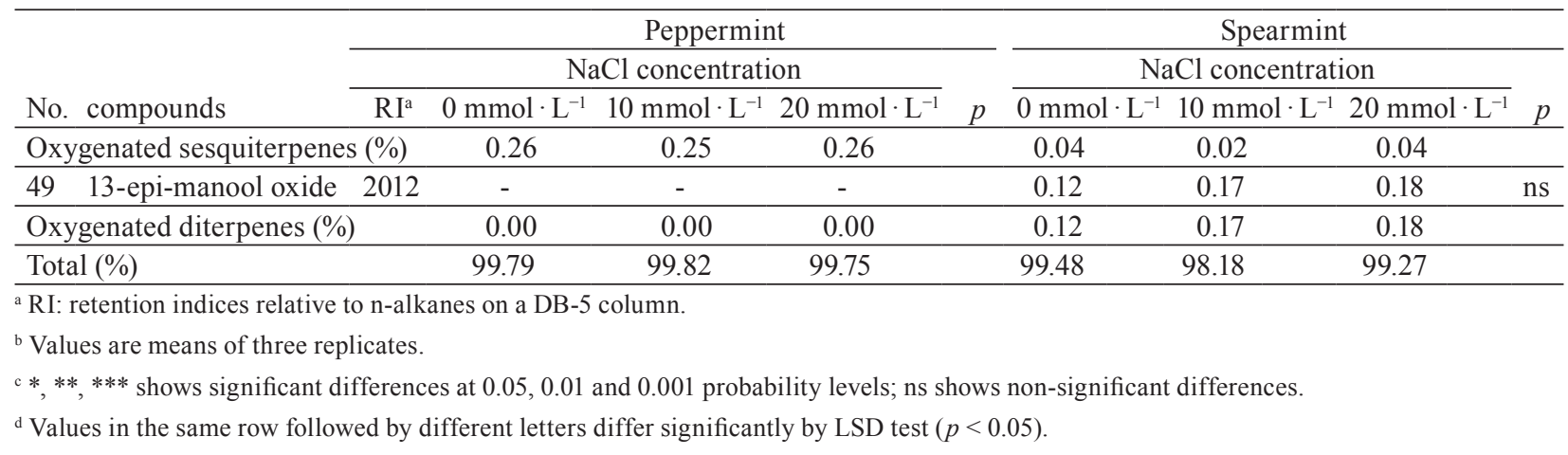

Table 4. Polyphenolic composition of peppermint and spearmint plants grown in floating system under three $\mathrm{NaCl}$ concentrations $\left(0 \mathrm{mmol} \cdot \mathrm{L}^{-1}, 10 \mathrm{mmol} \cdot \mathrm{L}^{-1}\right.$ or $\left.20 \mathrm{mmol} \cdot \mathrm{L}^{-1}\right)$.

\begin{tabular}{|c|c|c|c|c|c|c|c|c|c|}
\hline \multirow[b]{3}{*}{ No. } & \multirow[b]{3}{*}{ compounds (mg $\cdot 100 \mathrm{~g}^{-1}$ d.w.) } & \multicolumn{4}{|c|}{ Peppermint } & \multicolumn{4}{|c|}{ Spearmint } \\
\hline & & \multicolumn{3}{|c|}{$\mathrm{NaCl}$ concentration } & \multirow[b]{2}{*}{$p$} & \multicolumn{3}{|c|}{$\mathrm{NaCl}$ concentration } & \\
\hline & & $0 \mathrm{mmol} \cdot \mathrm{L}^{-1}$ & $10 \mathrm{mmol} \cdot \mathrm{L}^{-1}$ & $20 \mathrm{mmol} \cdot \mathrm{L}^{-1}$ & & $0 \mathrm{mmol} \cdot \mathrm{L}^{-1}$ & $10 \mathrm{mmol} \cdot \mathrm{L}^{-1}$ & $20 \mathrm{mmol} \cdot \mathrm{L}^{-1}$ & $P$ \\
\hline 1 & Vanillic acid & $0.34^{\mathrm{a}}$ & 0.34 & 0.27 & $\mathrm{~ns}^{\mathrm{b}}$ & 0.84 & 0.78 & 0.71 & ns \\
\hline 2 & 2,6-dihydroxybenzoic acid & 0.68 & 0.39 & 0.51 & ns & 0.77 & 0.61 & 0.77 & \\
\hline 3 & Syringaldehyde & 0.03 & 0.02 & 0.05 & $\mathrm{~ns}$ & 0.06 & 0.03 & 0.04 & \\
\hline 4 & Daphetin & 0.13 & 0.14 & 0.12 & $\mathrm{~ns}$ & 0.13 & 0.15 & 0.13 & $n$ \\
\hline 5 & Caffeic acid & 11.79 & 9.88 & 12.45 & ns & 13.23 & 14.18 & 16.72 & ns \\
\hline 6 & Ferulic acid & 0.23 & 0.32 & 0.24 & $\mathrm{~ns}$ & 0.29 & 0.26 & 0.24 & ns \\
\hline 7 & Caftaric acid & 19.35 & 17.40 & 23.29 & $\mathrm{~ns}$ & 13.73 & 18.10 & 15.76 & $\mathrm{n}$ \\
\hline 8 & Neochlorogenic acid & 5.24 & 4.72 & 5.45 & $\mathrm{~ns}$ & 3.06 & 3.64 & 3.62 & ns \\
\hline 9 & Chlorogenic acid & 4.62 & 4.89 & 5.97 & $\mathrm{~ns}$ & 4.47 & 6.18 & 5.43 & ns \\
\hline 10 & Rosmarinic acid & 287.81 & 257.40 & 373.28 & $\mathrm{~ns}$ & 417.62 & 489.75 & 491.95 & ns \\
\hline 11 & Sinapyl alcohol & 0.68 & 0.59 & 0.64 & $\mathrm{~ns}$ & 0.56 & 0.37 & 0.58 & \\
\hline 12 & Fertaric acid & 1.80 & 1.72 & 1.85 & $\mathrm{~ns}$ & 2.60 & 3.34 & 2.74 & ns \\
\hline 13 & $t$-coutaric & 0.76 & 1.17 & 1.29 & $\mathrm{~ns}$ & 1.14 & 1.41 & 1.20 & $\mathrm{n}$ \\
\hline 14 & Apigenin & 1.57 & 1.86 & 1.83 & $\mathrm{~ns}$ & 0.55 & 0.62 & 0.95 & $\mathrm{n}$ \\
\hline 15 & Luteolin & 7.50 & 7.14 & 8.38 & $\mathrm{~ns}$ & 1.85 & 2.30 & 2.62 & $\mathrm{n}$ \\
\hline 16 & Luteolin-7- $O$-glucoside & 0.88 & 0.98 & 1.02 & ns & 1.18 & 1.57 & 1.54 & ns \\
\hline 17 & Hesperidin & 128.98 & 124.94 & 149.51 & $\mathrm{~ns}$ & 88.72 & 78.69 & 88.95 & $n$ \\
\hline 18 & Apigenin-7-glucoside & 0.21 & 0.28 & 0.31 & $\mathrm{~ns}$ & 0.43 & 0.65 & 0.64 & ns \\
\hline 19 & Naringenin & 1.90 & 2.05 & 2.76 & ns & 1.08 & 1.27 & 1.18 & $\mathrm{n}$ \\
\hline 20 & Kaempferol-3-glucoside & 0.02 & 0.01 & 0.01 & $\mathrm{~ns}$ & 0.02 & 0.05 & 0.03 & $\mathrm{n}$ \\
\hline 21 & Arbutin & 0.07 & 0.08 & 0.08 & $\mathrm{~ns}$ & 0.13 & 0.11 & 0.08 & $\mathrm{n}$ \\
\hline 22 & Syringic acid & 0.76 & 0.68 & 0.61 & ns & 0.47 & 0.62 & 0.38 & ns \\
\hline 23 & Cryptochlorogenic acid & 16.22 & 16.78 & 20.73 & $\mathrm{~ns}$ & 15.40 & 21.39 & 19.05 & $\mathrm{n}$ \\
\hline 24 & Quercetin-3-glucoside & 0.23 & 0.15 & 0.26 & $\mathrm{~ns}$ & 0.34 & 0.32 & 0.35 & ns \\
\hline 25 & Quercetin-4-O-glucoside & 40.03 & 38.67 & 47.29 & $\mathrm{~ns}$ & 26.43 & 22.22 & 26.76 & ns \\
\hline 26 & Rutin & 1.09 & 1.26 & 1.52 & $\mathrm{~ns}$ & 2.47 & 1.82 & 1.73 & ns \\
\hline
\end{tabular}

${ }^{a}$ Values are means of three replicates.

$\mathrm{b} *, * *, * * *$ shows significant differences at $0.05,0.01$ and 0.001 probability levels; ns shows non significant-differences.

et al., 2019; Farahbakhsh et al., 2021), which may be explained by different genotypes, location or agronomic conditions, such as harvesting time, plant age, crop density, as well as growing substrate (soil against soilless NS). Rosmarinic acid and hesperidine were the main phenolic components in both peppermint and spearmint plants, which is in line with the findings of a more recent study in Iran (Farahbakhsh et al., 2021), which, too, observed significant antioxidant activity.
In our study, an increase in the above antioxidant components was observed only in spearmint grown in NS containing $20 \mathrm{mmol} \cdot \mathrm{L}^{-1} \mathrm{NaCl}$. Similar results have been observed in the carotenoid content of basil plants grown under different levels of saline conditions (Bernstein et al., 2010), as well as in the total phenolic content of marjoram and sage and the total antioxidant capacity of the latter (Jelali et al., 2011; Taârit et al., 2012), where the content of these components increased relatively while increasing the levels of salinity. Phenolics content and 
antioxidant capacity in lettuce plants grown in a floating hydroponic system and harvested 5 weeks after sowing were favoured by the moderate salt conditions induced after $\mathrm{CaCl}_{2}$ supplement in the NS (Borghesi et al., 2013).

High salinity may also influence individual polyphenolics' composition, as observed in rosemary plants grown under NSs where various salts had been added, but in the $\mathrm{NaCl}$ treatment no differences were found in phenolic diterpene concentrations (Tounekti et al., 2011), which is similar to the findings of the present study. Many researchers have reported contradictory results regarding variations in the essential oil content and its constituents in herbs grown under saline conditions. In less resistant species, like the Canadian mint and mint timija, a decrease in the essential oil content was observed when grown in high salinity of $>50 \mathrm{mmol} \cdot \mathrm{L}^{-1}$ $\mathrm{NaCl}$ (Kasrati et al., 2014; Yu et al., 2015). However, in more resistant species, such as marjoram, sage and basil, mild salinity stress may induce the production of essential oil until a maximum limit of salinity level and beyond that a decrease was observed (Bernstein et al., 2010; Jelali et al., 2011; Taârit et al., 2011). The type of salt also constitutes an important factor, as the essential oil content of basil plants decreased while grown in NS containing $25 \mathrm{mmol} \cdot \mathrm{L}^{-1} \mathrm{Na}_{2} \mathrm{SO}_{4}$ and increased while grown in $50 \mathrm{mmol} \cdot \mathrm{L}^{-1} \mathrm{NaCl}$ (Tarchoune et al., 2013). Changes in the essential oil content were often accompanied by a simultaneous modification in the relative concentration of the essential oil constituents, resulting in a significant effect on the oil's compositional profile.

\section{CONCLUSIONS}

In conclusion, peppermint and spearmint are suitable for a sustainable environmentally friendly soilless production in the floating system under mild salinity conditions $\left(10 \mathrm{mmol} \cdot \mathrm{L}^{-1}\right.$ to $\left.20 \mathrm{mmol} \cdot \mathrm{L}^{-1} \mathrm{NaCl}\right)$, without any adverse effects on the fresh biomass yield, the nutritional characteristics or the essential oil content and composition. Indeed, spearmint benefits from a slight salinity stress increase in the NS, as the nitrate content decreased and the secondary metabolites increased. Both species may be grown in greenhouse production units that do not have access to high quality water. The essential oil and the phenolic composition of both peppermint and spearmint were not affected, indicating that these two species may profitably be grown even under $20 \mathrm{mmol} \cdot \mathrm{L}^{-1} \mathrm{NaCl}$ without suffering from oxidative stress or from risking any market value loss.

\section{ACKNOWLEDGEMENTS}

All authors had significant contribution and have been included in the authorship. No further assistance was provided and therefore no further acknowledgement is to be included.

\section{FUNDING}

This research received no external funding.

\section{AUTHOR CONTRIBUTIONS}

D-C.A., P.T. and A.S.S.: conceptualisation. P.T., D-C.A., D.S.K. and E.S.: methodology. P.T., D-C.A. and E.S.: software. A.S.S., P.C. and S.M.: formal analysis. D.S.K. and D-C.A.: investigation. P.T., D-C.A. and E.S.: data curation. P.T, D.S.K, D-C.A. and E.S.: writing and original draft preparation. S.M, P.C. and A.S.S.: writing, review and editing. P.T. and A.S.S.: supervision.

\section{CONFLICT OF INTEREST}

All authors declare that no conflicts of interest exist.

\section{REFERENCES}

AdAms, R. (2007). Identification of essential oil components by gas chromatography/Mass Spectroscopy. Carol Stream, USA: Allured Publishing.

Alaghmand, S., Beecham, S., and Hassanli, A. (2013). Impacts of groundwater extraction on salinization risk in a semi-arid floodplain. Natural Hazards and Earth System Sciences, 13, 3405-3418.

Arslan, H., Kiremit, M. S., And GünGÖr, A. (2018). Impacts of different water salinity levels on salt tolerance, water use, yield, and growth of chives (Allium schoenoprasum). Communications in Soil Science and Plant Analysis, 49, 2614-2625.

Atzori, G., Mancuso, S., And Masi, E. (2019). Seawater potential use in soilless culture: A review. Scientia Horticulturae, 249, 199-207.

Bernstein, N., Kravchik, M., and Dudai, N. (2010). Salinity-induced changes in essential oil, pigments and salts accumulation in sweet basil (Ocimum basilicum) in relation to alterations of morphological development. Annals of Applied Biology, 156, 167-177.

Blom-Zandstra, G., and Lampe, J. E. M. (1983). The effect of chloride and sulphate salts on the nitrate content in lettuce plants (Lactuca sativa L.). Journal of Plant Nutrition, 6, 611-628.

Borghesi, E., Carmassi, G., Uguccioni, M. C., Vernieri, P., And Malorgio, F. (2013). Effects of calcium and salinity stress on quality of lettuce in soilless culture. Journal of Plant Nutrition, 36, 677-690.

Brand-Williams, W., Cuvelier, M. E., and Berset, C. (1995). Use of a free radical method to evaluate 
antioxidant activity. LWT - Food Science and Technology, 28, 25-30.

Cataldo, D. A., Maroon, M., Schrader, L. E., And Youngs, V. L. (1975). Rapid colorimetric determination of nitrate in plant tissue by nitration of salicylic acid. Communications in Soil Science and Plant Analysis, 6, 71-80.

Charles, D. J. (ED.) (2013). Antioxidant properties of spices, herbs and other sources. New York, USA: Springer.

Chauhan, R. C., Nautiyal, M. C., and Tava, A. (2010). Essential oil composition from aerial parts of Mentha spicata L. Journal of Essential Oil-Bearing Plants, 13, 353-356.

Chrysargyris, A., Nikolaidou, E., Stamatakis, A., And Tzortzakis, N. (2017). Vegetative, physiological, nutritional and antioxidant behavior of spearmint (Mentha spicata L.) in response to different nitrogen supply in hydroponics. Journal of Applied Research on Medicinal and Aromatic Plants, 6, 52-61.

Dat, J., Vandenabeele, S., Vranová, E., Van Montagu, M., Inzé, D., And Van Breusegem, F. (2000). Dual action of the active oxygen species during plant stress responses. Cellular and Molecular Life Sciences, 57, 779-795.

Estaji, A., Roosta, H. R., Rezaei, S. A., Hosseini, S. S., and Niknam, F. (2018). Morphological, physiological and phytochemical response of different Satureja hortensis L. accessions to salinity in a greenhouse experiment. Journal of Applied Research on Medicinal and Aromatic Plants, 10, 25-33.

Farahbakhsh, J., Najafian, S., Hosseinifarahi, M., AND GHolipour, S. (2021). Essential oil composition and phytochemical properties from leaves of felty germander (Teucrium polium L.) and spearmint (Mentha spicata L.). Journal of Essential OilBearing Plants, 24, 147-159.

García-Caparrós, P., Llanderal, A., Pestana, M., Correia, P. J., AND LAO, M. T. (2017). Lavandula multifida response to salinity: Growth, nutrient uptake, and physiological changes. Journal of Plant Nutrition and Soil Science, 180, 96-104.

Hinsinger, P., Plassard, C., Tang, C., and Jaillard, B. (2003). Origins of root-mediated $\mathrm{pH}$ changes in the rhizosphere and their responses to environmental constraints: A review. Plant and Soil, 248, 43-59.

Jelali, N., Dhifi, W., Chahed, T., and Marzouk, B. (2011). Salinity effects on growth, essential oil yield and composition and phenolic compounds content of marjoram (Origanum majorana L.) leaves. Journal of Food Biochemistry, 35, 1443-1450.

Jungklang, J., Usui, K., and Matsumoto, H. (2003). Differences in physiological responses to $\mathrm{NaCl}$ between salt-tolerant Sesbania rostrata Brem. \& Oberm. and non-tolerant Phaseolus vulgaris L. Weed Biology and Management, 3, 21-27.

Kasrati, A., Alaoui Jamali, C., Bekkouche, K., Wohlmuth, H., Leach, D., And AbBaD, A.
(2014). Plant growth, mineral nutrition and volatile oil composition of Mentha suaveolens subsp. timija (Briq.) Harley cultivated under salt stress conditions. Industrial Crops and Products, 59, 80-84.

Lazof, D. B., And Bernstein, N. (1998). The $\mathrm{NaCl}$ induced inhibition of shoot growth: The case for disturbed nutrition with special consideration of calcium. Advances in Botanical Research, 29, 113-189.

Lee, G., Carrow, R. N., and Duncan, R. R. (2004). Photosynthetic responses to salinity stress of halophytic seashore paspalum ecotypes. Plant Science, 166, 1417-1425.

Lichtenthaler, H. K., and Wellburn, A. R. (1983). Determinations of total carotenoids and chlorophylls $\mathrm{a}$ and $\mathrm{b}$ of leaf extracts in different solvents. Biochemical Society Transactions, 11, 591-592.

MunNs, R. (1993). Physiological processes limiting plant growth in saline soils: Some dogmas and hypotheses. Plant, Cell and Environment, 16, 15-24.

Neocleous, D., Ntatsi, G., And Savvas, D. (2017). Physiological, nutritional and growth responses of melon (Cucumis melo L.) to a gradual salinity builtup in recirculating nutrient solution. Journal of Plant Nutrition, 40, 2168-1280.

Niu, G., Sun, Y., Masabni, J. G. (2018). Impact of low and moderate salinity water on plant performance of leafy vegetables in a recirculating NFT system. Horticulturae, 4(1), 6, doi: 10.3390/ horticulturae4010006.

Pardossi, A., Bagnoli, G., Malorgio, F., Campiotti, C. A., And Tognoni, F. (1999). $\mathrm{NaCl}$ effects on celery (Apium graveolens L.) grown in NFT. Scientia Horticulturae, 81, 229-242.

Peter, K. V. (Ed.) (2001). Handbook of herbs and spices. Cambridge, England: Woodhead Publishing Limited.

Pulido-Bosch, A., Rigol-Sanchez, J. P., Vallejos, A., Andreu, J. M., Ceron, J. C., Molina-Sanchez, L., AND SolA, F. (2018). Impacts of agricultural irrigation on groundwater salinity. Environmental Earth Sciences, 77, 1-14.

QiU, N., AND Lu, C. (2003). Enhanced tolerance of photosynthesis against high temperature damage in salt-adapted halophyte Atriplex centralasiatica plants. Plant, Cell and Environment 26, 1137-1145.

Rezaie, N., Razzaghi, F., and Sepaskhah, A. R. (2019). Different levels of irrigation water salinity and biochar influence on faba bean yield, water productivity, and ions uptake. Communications in Soil Science and Plant Analysis, 50, 611-626.

Riachi, L. G., and De Maria, C. A. B. (2015). Peppermint antioxidants revisited. Food Chemistry, 176, 72-81.

Rodríguez-Hidalgo, S., Artés-Hernández, F., Gómez, P. A., Fernández, J. A., And Artés, F. (2010). Quality of fresh-cut baby spinach grown under a floating trays system as affected by nitrogen fertilisation 
and innovative packaging. Journal of the Science of Food and Agriculture, 90, 1089-1097.

Rouphael, Y., Cardarelli, M., Bassal, C., Leonardi, C., Giuffrida, F., and Colla, G. (2012). Vegetable quality as affected by genetic, agronomic and environmental factors. International Journal of Agriculture, Environment and Food Sciences, 10, 680-688.

Santamaria, P. (2006). Nitrate in vegetables: Toxicity, content, intake and EC regulation. Journal of the Science of Food and Agriculture, 86, 10-17.

Scalbert, A., Monties, B., And Janin, G. (1989). Tannins in wood: comparison of different estimation methods. Journal of Agricultural and Food Chemistry, 37, 1324-1329.

TAÂrit, M. B., Msaada, K., Hosni, K., And Marzouk, B. (2011). Physiological changes and essential oil composition of clary sage (Salvia sclarea L.) rosette leaves as affected by salinity. Acta Physiologiae Plantarum, 33, 153-162.

TaÂrit, M. B., Msaada, K., Hosni, K., And Marzouk, B. (2012). Physiological changes, phenolic content and antioxidant activity of Salvia officinalis L. grown under saline conditions. Journal of the Science of Food and Agriculture, 92, 1614-1619.

Tarchoune, I., BaÂtour, O., Harrathi, J., Cioni, P. L., LachaÂl, M., Flamini, G., and Ouerghi, Z. (2013). Essential oil and volatile emissions of basil (Ocimum basilicum) leaves exposed to $\mathrm{NaCl}$ or $\mathrm{Na}_{2} \mathrm{SO}_{4}$ salinity. Journal of Plant Nutrition and Soil Science, 176, 748-755.

Thakur, M., Bhattacharya, S., Khosla, P. K., and Puri, S. (2019). Improving production of plant secondary metabolites through biotic and abiotic elicitation. Journal of Applied Research on Medicinal and Aromatic Plants, 12, 1-12.

Tounekti, T., Vadel, A. M., Ennajeh, M., Khemira, H., and Munné-Bosch, S. (2011). Ionic interactions and salinity affect monoterpene and phenolic diterpene composition in rosemary (Rosmarinus officinalis). Journal of Plant Nutrition and Soil Science, 174, 504-514.
Urrestarazu, M., AND García, M. (2000). Modeling electrical conductivity management in a recirculating nutrient solution under semiarid conditions. Journal of Plant Nutrition, 23, 457-468.

Verma, N., And Shukla, S. (2015). Impact of various factors responsible for fluctuation in plant secondary metabolites. Journal of Applied Research on Medicinal and Aromatic Plants, 2, 105-113.

Vimolmangkang, S., Sitthithaworn, W., Vannavanich, D., Keattikunpairoj, S., and Chittasupho, C. (2010). Productivity and quality of volatile oil extracted from Mentha spicata and $M$. arvensis var. piperascens grown by a hydroponic system using the deep flow technique. Journal of Natural Medicines, 64, 31-35.

Vrhovsek, U., Masuero, D., Gasperotti, M., Franceschi, P., Caputi, L., Viola, R., and Mattivi, F. (2012). A versatile targeted metabolomics method for the rapid quantification of multiple classes of phenolics in fruits and beverages. Journal of Agricultural and Food Chemistry, 60, 8831-8840.

WojdyŁo, A., Oszmiański, J., And Czemerys, R. (2007). Antioxidant activity and phenolic compounds in 32 selected herbs. Food Chemistry, 105, 940-949.

Yousefi, H., Dalir, N., Rahnemaie, R., and Babaei A. (2020). The alleviation of salinity-induced stress by using boron in soilless grown rose. Journal of Plant Nutrition, 43, 526-537.

Yu, X., Liang, C., Chen, J., Qi, X., Liu, Y., And LI, W. (2015). The effects of salinity stress on morphological characteristics, mineral nutrient accumulation and essential oil yield and composition in Mentha canadensis L. Scientia Horticulturae, 197, 579-583.

Zekri, N., Elazzouzi, H., El Makhoukhi, F., Alaoui El Belghiti, M., and Zair, T. (2019). Drying effect on yields and chemical composition of essential oils extracted from the Moroccan Mentha spicata L. aerial parts. Journal of Essential Oil-Bearing Plants, 22, 789-798.

Received: April 29, 2021; accepted July 26, 2021. 